\title{
Neoliberalism in Argentina and Chile: common antecedents, divergent paths
}

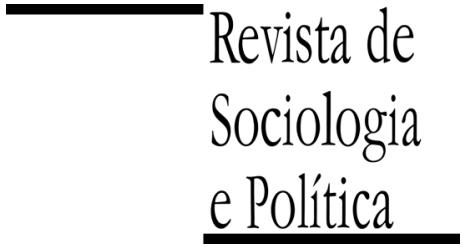

DOI 10.1590/1678-987315235502

\section{Tomás Undurraga}

\begin{abstract}
This paper contrasts the experiences of neoliberalism in Argentina and Chile, exploring why two countries that implemented apparently similar market reforms came to different stances on marketization: a post-neoliberal politics in Argentina, and a tempered neoliberalism in Chile that has only recently come under scrutiny. The paper traces the common antecedents that inspired these reforms and the different outcomes and reactions that they produced. In contrast to recent literature, which emphasizes one or another explanatory factor, this article offers a synthetic comparison of the historical, political, economic, and ideological factors in play, helping to understand how capitalists achieved a hegemonic class position in Chile and not in Argentina.
\end{abstract}

KEYWORDS: Neoliberalism; Argentina; Chile; Post-neoliberalism; Capitalist class formation.

Recebido em 23 de Setembro de 2014. Aceito em 17 de Fevereiro de 2015.

\section{Introduction ${ }^{1}$}

${ }^{1}$ We thank the anonymous reviewers of the Revista de Sociologia e Política for their comments on this article.

\footnotetext{
2 Their per capita GDP based on purchasing-power-parity (PPP) in 2010 was US $\$ 15,854.366$ and US $\$ 15,001.949$ respectively (IMF 2011), while their unemployment rates are also similar: 7.8 percent in Argentina and 8.3 percent in Chile (CEPAL 2011).
}

$\mathrm{T}$ he political and economic history of Argentina and Chile in the last four decades have many commonalities. Both countries were subject to early experiments in free market reform under dictatorial regimes in the 1970s. While the 'Chicago boys' led radical transformations under the Pinochet regime (1973-1990) in Chile, Finance Minister Martínez de Hoz attempted to implement an analogous programme under the Argentinean Junta (1976-1983). In Argentina, however, those reforms only fully took root a decade later with President Menem's (1989-1998) implementation of the 'convertibility plan'. During the 1990s, both nations were held up as 'poster children' of the Washington Consensus. Following market reforms both countries have pursued agro-export strategies, reinforcing the desindustrialisation of their modes of production (Schneider 2009). Soybeans, beef and wheat lead Argentinean exports while Chilean exports are dominated by copper, salmon and timber. According to some economic benchmarks, both countries appear on equal footing, qualifying as upper-middle income economies ${ }^{2}$.

Despite some of these capitalist commonalities (Streeck 2010), the neoliberal trajectories followed by these countries diverged. In Chile, the 'social market economy' (Muñoz Goma 2007) was supported by the political-economic elites for two decades (1990-2010), preventing major challenges to the 'market model'. Despite the fact that free market 'adjustments' produced huge costs in Chile (e.g. the 1982 banking collapse and the high unemployment that followed) the constrictions of dictatorship provided the conditions for private expansion (Ffrench-Davis 2007). Post-dictatorship, four centre-left democratic governments led by the 'Concertación' coalition (1990-2010) maintained free market policies. Concertación did not break with neoliberalism, but only aimed to temper it by orchestrating greater social equality (E. Silva 2009). Despite structural inequalities, the improved material conditions brought by capitalist modernization $-e . g$. better quality of housing, roads and infrastructure, increased private consumption and access to education - helped create support for 
continuing the neoliberal model. The centre-right government of businessmen Sebastián Piñera (2010-2014), then further reinforced the market model.

However, since the cycle of mobilizations that started with the 'penguin' student movement in 2006 (Donoso 2013) and continued gathering momentum in 2011 with protests against for-profit education, neoliberalism in Chile has been challenged in unprecedented ways (Mayol 2012). Growing discontent with structural inequalities and a frustrated sense that the political class is out of touch with popular needs and demands has produced social unrest unseen since the Pinochet years. Protests have focused on access to education as well as environmental concerns (Aysen), workers' conditions (Codelco) and consumer rights (La Polar), among others. Scholars (and politicians) have argued that Chile is entering a new political cycle in which the subjugation of politics by economics is being questioned, with calls for building a more social democratic model (Atria 2013; Fuentes 2013; Atria et al., 2013). The promises of the re-elected President Bachelet (2014-2018) - e.g. reforms in education, taxation, and a new constitution - indicate a new willingness to move away from some neoliberal conventions. The extents to which reform will be embraced by the congress and made practical remain to be seen.

In Argentina, on the other hand, neoliberal policies came under severe scrutiny much earlier, with the response to the country's 2001 crisis proving pivotal. In effect, a social reaction against 'market forces' has mobilized the country for over a decade (Villalón 2007). The neoliberal model driven by Menem (19891999) was associated with middle class consumerism, but also with corruption and unemployment (Novaro 2006). The poor performance of the Washington Consensus policies led to the collapse of the De la Rua government (19992001 ) and the convertibility plan. The governments of Néstor Kirchner (20032007) and Cristina Fernandez de Kirchner (2007-2011; 2011-2015) subsequently capitalised on the backlash against the 1990s reforms. Their postneoliberal politics reinforced the activation of popular actors, enhanced the legitimacy of the state's right to intervene in structuring economic affairs, and strengthened economic and social rights (Etchemendy 2011).

Despite the positive political and economic results of the Kirchner administrations (at least until 2011), their post-neoliberal politics have engendered controversy - both domestically and abroad. There have been repeated clashes between the government and agro-industrialists over taxation and price controls (2008-2009), confrontations with the Clarín media group concerning television contracts and the media law, disputes with private consultants about the inflation rates of INDEC (Institute of National Statistics), as well as disputes concerning the nationalization of pension funds (AFJP), Aerolíneas Argentinas and YPF (Oil company), among many others. Just recently (August 2014), the government's clash with foreign bondholders refusing to re-negotiation the country's 2005 debt, left Argentina in 'technical default'. The rising inflation (over $28 \%$ in 2013 according to private consultants - Revista América Economía, 14 Jan. 2014) and the government's unsuccessful attempts to reduce the dollarization of the economy have provoked national distress. Contesting neoliberalism has not been easy for the Kirchners, and their politics have put their opponents on the counter-offensive, with mixed results for Argentine society as a whole.

In the mainstream political and sociological literature, competing accounts explain why neoliberalism penetrated further in Chile than in Argentina. Some scholars focus on the political conditions under which neoliberal experiments were implemented during the military regimes (Huneeus 2001; L. Taylor 1998; Huneeus 2001; Pucciarelli 2004; 2011; Novaro 2006; Boisard \& Heredia 2010). Sector analyses have tended to study the implementation of reforms in particu- 
lar areas (e.g. employment, education, health coverage, pensions), looking at the differing paths of adjustment through which these processes of 'marketization' became viable (Kurtz 2001; M. Taylor 2006; Ffrench-Davis 2010; Etchemendy 2011). Other studies have compared the position of actors within national economic systems, such as industrial relations (Atzeni, Durán-Palma \& Ghigliani 2011), business politics (E. Silva 1996; Schneider 2004), tax systems (Fairfield 2010), or models of citizenship (L. Taylor 1998). Another type of research has focused on the ideas that have influenced the economic thinking of policy makers, particularly ideas coming from the Economics Department at the University of Chicago (Valdés 1995; Centeno \& Silva 1998; Biglaiser 2002; Dezalay \& Garth 2002; Heredia 2008; P. Silva 2008; Montecinos \& Markoff 2009; Gárate 2012). Finally, scholars have studied post-neoliberal reactions to market expansion in Latin America, often contrasting Argentina's strong social movements with the more institutional response that has been characteristic of Chilean society (Villalón 2007; E. Silva 2009; Panizza 2009; Han 2012; Grugel \& Riggirozzi 2012).

In light of the richness of the work that has been done on this issue so far, this paper seeks to deliver a synthetic overview that allows us to see the varied factors at play in producing these divergences. That is, instead of singling out any one dominant set of factors, I seek to flesh out an explanatory picture that shows how many political, economic, institutional, and ideological variables contributed to the divergent paths. A common hazard among scholars seeking to interpret market reforms and their impact lies in over-emphasizing particular explanatory factors so to achieve theoretical tidiness or disciplinary distinctness. Equally, others tend to overstate the importance of national characteristics. This paper, by contrast, seeks to show that a comparative, multi-variable approach may provide a clearer overview of these countries' trajectories.

The paper uses the existing literature as well as interviews with intellectuals, politicians and business figures involved in recent changes in these countries ${ }^{3}$. The article is organised as follows. First, a brief discussion about the nature of neoliberalism, and its key dimensions is developed. Section 3 displays the core of the paper, comparing the neoliberal trajectories of Argentina and Chile along nine distinct dimensions. Section 4 concludes by discussing the current state of neoliberalism in these countries.

\section{Neoliberalism: the disenchantment of politics by economics}

3 This paper elaborates on 120 interviews conducted in 2008 and 2009 in Santiago (64) and Buenos Aires (56) with business scholars, policymakers, managers, journalists and intellectuals who have studied or participated in recent capitalist transformations in these countries. A full version of that research was published in Undurraga (2014).
Neoliberalism is a loose concept largely associated with critical perspectives on the globalisation discourse. Rather than a succinct, clearly defined political philosophy (Mirowski \& Plehwe 2009), it is linked with various policy positions, economic interests and cultural practices. Perhaps most commonly, the neoliberal project is identified with a set of policies that encapsulate the prescriptive development stance of 'Washington Consensus' institutions from the 1980's - i.e. the International Monetary Fund (IMF), the World Bank, and the International Development Bank (IDB). These policies sought a retrenchment in the state's role, privatization of public assets and cuts in public expenditure. They identified government as part of the problem of underdevelopment, citing corruption, bad distribution of resources and inefficiency (Williamson 1990).

As a term, however, it gets used as both an oppositional slogan and as an analytical construction. Considered from the latter point of view, at least four interlinking dimensions may be identified as key features: neoliberalism as economic theory; as restructuring ethos; as a depoliticizing technique of governmentality; and as a means of restoring class power. For the purposes of this paper, I use these four dimensions to shed light on the different fates of market policies in Argentina and Chile. 
First, as an economic theory, neoliberalism builds on the foundations of nineteenth century economic liberalism, that is, economic laissez-faire. Its roots are in the classical economic thinking of Adam Smith, David Ricardo and John Stuart Mill and recent writings of Milton Friedman and Friedrich Hayek, among others. Neoliberalism claims that society as a whole is best served by maximum market freedom and minimum intervention by the state, claiming that such a situation will enable individual entrepreneurial freedoms and skills to be maximally developed. In this context, the government's role is limited to providing security, protecting private property, and creating and maintaining markets (Harvey 2005).

Second, as a restructuring ethos (Peck, Theodore \& Brenner 2009), neoliberalism attempts to replace political judgement and discourse with economic norms and methods of evaluation (Davies 2014). Rather than a closed totality of ideas or a typological state form, neoliberal is here conceived as a private form of social rule marked by the dominance of giant corporations, the privatization of public firms, and the colonization of state services by new public management (Crouch 2011). Understood in this way, neoliberalism is less typically concerned with expanding markets per se, than in expanding the reach of market based principles and techniques of evaluation. As Davies (2014, p. 4) stresses, "the central defining characteristic of all neoliberal critique is its hostility to the ambiguity of political discourse, and the commitment to the explicitness and transparency of quantitative, economic indicators, of which the market price system is the model. Neoliberalism is the pursuit of the disenchantment of politics by economics".

Neoliberalism may also be used as depoliticizing technique of governmentality, one that effectively helps to de-collectivize society through removing the institutions that sanction public action. This aspect of neoliberalism was famously brought forward in Foucault's (2008) lectures on biopolitics and Miller and Rose (2008) work on governmentality. According to this logic, neoliberalism operates as a technique of 'governmentality' that aims to shape citizens' attitudes and behaviours by reinforcing the autonomy of individuals as against the agency of politicized collectives. Based on the promise that markets will provide steady and increasing access to consumption in the future, neoliberalism aims to discipline both citizens and political elites, postponing the social demands of the former, and containing the internal conflicts of the latter (Guell 2009).

A fourth feature of the neoliberal project consists in its ambition to restore class power (Dumenil \& Levy 2004). Harvey (2005, p. 15) argues that neoliberalism from the beginning was a project to achieve the restoration of class power guided by business elites and international institutions. In 1971 the labour movement enjoyed its greatest global expansion, extending the collectivization of popular demands (Therborn 2011). The global economic elites generally regarded this largely anti-corporate, anti-imperialist movement as having gone too far, calling for renewing the conditions for capitalist's expansion (Crozier, Huntington \& Watanuki 1975). Conservative think tanks like the Heritage Foundation and the American Enterprise Institute linked their defence of 'individual freedoms' to the defence of free markets (Medved 2012). In this sense, neoliberalism would be a strategy for institutional transformation that promised to resolve the capitalist crisis of the 1970s providing new guarantees for the accumulation of wealth. The rising inequality across western countries linked to marketization and globalisation in the last four decades would come to confirm this feature of the neoliberal project (Piketty 2014; Wilkinson 2005; Therborn 2013). 
One way of conceiving neoliberalism that brings together certain aspects of all four dimensions is due to Mirowski and Plehwe (2009). They argue that neoliberalism is, effectively, a "thought collective", where by this they mean a multi-centric movement anchored in a network of think tanks and pro-market institutions that connect political, economic and scientific elites. Some of the epistemic commitments that mark this "thought collective" are: markets must be built, they do not emerge spontaneously; redefining rather than merely destroying or minimizing the state is in the best interest of the market and those that profit from it; the best solutions to problems caused by the market are themselves market-based (e.g. carbon credits, the sale of human organs or vouchers for education) (Mirowski 2013).

Considering these four dimensions, in what follows, I compare nine features of the neoliberal experiences in Argentina and Chile.

\section{Neoliberalism in Argentina and Chile: common antecedents, divergent paths}

III.1. Neoliberalism was attractive to the militaries of both countries in the 1970s as a depoliticizing mechanism for re-establishing order

Neoliberal experiments in Argentina and Chile emerged in similar contexts. Both countries were facing political, economic and social unrest at the beginning of the 1970s. Social forces calling for the extension of the state - i.e. Peronism in Argentina and Allende's Unidad Popular in Chile - disputed the position and benefits of elites. The diagnoses of the militaries and of the traditional elites that supported the coups were similar; years of collectivization, distributive policies, and inflation had increased conflicts and weakened growth. Order needed to be re-established and societies had to be 'normalised' (Boisard $\&$ Heredia 2010). The regimes' aims were broadly similar; they sought to end social unrest and economic stagnation by dismantling the remnants of import substitution policies and by imposing market relationships as the predominant form of social organisation (M. Taylor 2006). The deregulation and opening of the economies, the dissolution of parliament, and the banning of political parties, and in the Chilean case the adoption of a new constitution (1980), were all part of a restructuring project to fashion a depoliticized and market-driven society (L. Taylor 1998).

Likewise, both regimes sought to carry out an 'ideological cleansing' of political movements. US-supported military coups were fomented internally by ruling elites, who saw in dictatorial regimes a way to assert class power and protect their privilege from political threat (Harvey 2005). Both coups occurred in contexts of class conflict: desire for revenge against agitators, left-wing guerrillas, as well as unions provoked military interventions (L. Taylor 1998). In Argentina, the so-called El Proceso de Reorganización Nacional (1976-1983) aimed to undermine the sources of Peronist power, notably the trade union movement and the industrial sector that had become accustomed to state protection (Novaro 2006). Similarly, the coup in Chile was directed not only against the Unidad Popular supporters, but also against revolutionary discourse and appeals to class struggle (Camargo Brito 2008). As declared in the 1980s Constitution, the military aimed to "give Chile a new institutional basis cleansing our democratic system of the vices that might lead to its destruction [and to] rebuild the country morally, institutionally and materially" (Chile 1988, p.24).

The brutal military regimes in Chile (1973-1990) and Argentina (19761983) had the same peculiarity of combining widespread repression and radical free market reform. This combination is by no means obvious (Biglaiser 2002). The military depends on state resources, to which neoliberal policies restrict access. Historically, both militaries had regarded their nationalized industries as 
key to defending sovereignty and national security in the context of a strong state. The prospect of leaving national industries and the economy open to international competition was difficult for many military officers in both countries to accept (Canelo 2004; 2008; Valdivia 2003).

On the whole, however, neoliberalism reform was attractive to both militaries because of the restructuring of social relations it promised and the depoliticizing effects it seemed to entail. The regulatory role of the markets was presented by monetarist economists as an effective mechanism for dismantling enclaves of collective action, and diffusing group pressure on the state (L. Taylor 1998). 'Natural competition' between individuals was conceived as a neutralizing way of solving the distributive puzzle. Monetarism in this sense functioned not only as a 'pure' economic theory, but also as a technology of governmentality (Foucault 2008). In other words, what neoliberalism offered to the military regimes was an effective way of 'governing at a distance', enabling them to disarm social forces and re-establish order, without appearing to compromise individual autonomy (Fridman 2010).

III.2. Monetarism was controversial within both military regimes, but Pinochet had greater power for implementing radical market reforms

The implementation of free market policies tends to be portrayed as a vertical imposition that rapidly gained followers in Chile (Harvey 2005; Klein 2007), whereas the Argentinean process is presented as a less straightforward experience (Canelo 2004; Novaro 2006). Rather than being the result of a coherent and premeditated programme, the execution of these policies in both countries was the product of trial and error, of experimentation (Kurtz 1999; Farías 2014). Political clashes and internal power struggles within the Juntas were initially similar in both countries. The military regimes themselves, however, were quite different. As Boisard and Heredia (2010, p. 5) point out, the Chilean dictator won the nickname of 'sultan', in light of his capacity to concentrate power and to ensure a pyramidal form of allegiance, while the Argentinean dictatorship was described as 'feudal', because of the opposition between different groups within the army. Just after the coup, the Chilean Junta decided to distribute government evenly between the military branches, resulting in a tripartite, corporatist power-sharing arrangement (Cavallo, Salazar \& Sepúlveda 1988). A few months after the 1973 coup, however, Pinochet imposed his authority inside the Junta arguing that short-term political stability required a firm hand. After serious clashes between the military branches, Pinochet conquered the presidential office in December 1974 (Valdivia 2003). After that, the Junta was limited to scrutinizing decisions made by the executive.

The more dispersed regime in Argentina, by contrast, never achieved the concentration of power attained by Pinochet. Internal disputes on political and economic issues were evident from the earliest military pronouncements. While the colorado faction sought to erase every vestige of Peronism from Argentinean politics, the azules advocated including Peronism (sans Perón) in the political system (Canelo 2004). The coup of 1976 was led by the most neoliberal colorados while the azules were discredited by the failure of the government formed after the 1966 coup (Boisard \& Heredia 2010). The colorados sought to eradicate Peronism from the political map, but, instead of proscribing it, as in previous coups, they decided to attack the social structures that made such a movement possible, diminishing the powers of mass mobilization (Fridman 2010, p.280).

The monetarist doctrine was not dominant in the early economic thinking of either military government. In Chile, the takeover of the 'Chicago boys', the group of technocrats that promoted market reforms, began in 1975. The Chi- 
cago boys were convinced they needed to implement their policies by 'shock', since they assumed that gradual implementation would provoke greater resistance. The new policymakers believed that the only way to break the conditions that condemned Chile to 'backwardness' was to insulate themselves from the pressure of unions and business elites demanding state support (E. Silva 1996). As part of 'opening the economy', more than 200 state-owned industrial, financial and commercial enterprises were sold in the 'first wave' of privatization (Gárate 2012). As Klein (2007) underlines, this economic 'shock therapy' was imposed in a moment of low resistance, following two years of brutal social repression. Then, the visit of Chicago academics Milton Friedman and Arnold Harberger in 1975 aimed to validate the liberalising policies.

With the Chilean experience in mind, the Argentinean Junta appointed the monetarist Martínez de Hoz as Minister of Finance in 1976. Despite an enthusiastic response to his liberal plans from bankers, persistent differences across the private sector and fragmentation within the army constrained their full implementation (Novaro 2006). Officers from each armed force were able to veto ministerial decisions, causing a radicalization of conflict between military branches and the liberal civilian team (Canelo 2004; Boisard \& Heredia 2010).

Because the retrenchment of the state generated resistances, economic reforms were not easy to install. Reactions, however, were different in both countries. With the support of Pinochet, the Chicago boys applied a shock programme despite recession, unemployment, and complaints from businesses. The Chilean dictatorship was able to impose social discipline not just on the working classes, but also on various industrial sectors. The situation was different in Argentina after the 1976 military coup. The stronger industrial sectors successfully resisted reform, forcing compensation from the state and demanding especially tailored arrangements (Etchemendy 2011). Martínez de Hoz attempted to accommodate sector pressures in order to win support for the process of reform. He also scaled back his ambitions, concentrating on the areas where he could advance: trade policy, exchange rate policy, and the financial system (Novaro 2006, p.94), while letting go of structural changes that would have been more extensive.

\section{III.3. Chicago economists and their monetarist ideas penetrated far deeper in Chile than in Argentina}

The remarkable turn towards neoliberalism in these countries is linked with the U.S. interest in influencing Latin American elites, in an explicit attempt to seek allies in the fight against communism. Since the 1950s, well-coordinated socialization efforts by private foundations attempted to challenge CEPAL's supremacy in Latin America (Valdés 1995), seeking to establish links with businessmen, political parties, the armed forces and the media, with the intention to influence public policy (Centeno \& Silva 1998). The University of Chicago was particularly influential in this capacity, boosting monetarist views through a radical critique of Keynesian interventionism. Chicago signed exchange agreements with several universities, where students received training in neoclassical economics. The School of Economics of Pontificia Universidad Católica (PUC) in Chile and the University of Cuyo in Mendoza and, later, the Centre for Macroeconomic Studies (CEMA) in Buenos Aires were the main institutions that disseminated monetarist ideas in these countries.

The 'Chicago boys' in Chile had its origins in this economic-educative partnership established in 1955 called Project Chile (Valdés 1995). Students from PUC that received post-graduate training in Chicago then re-organized the faculty of economics at PUC, and later played a key role in guiding the structural transformations of Pinochet's regime (Gárate 2012). The alliance with Jaime Guzmán and the 'gremialistas' since the late 1960s afforded these technocrats 
${ }^{4}$ The gremialistas are a conservative right wing movement that arose from PUC School of Law in 1967 with the intention to depoliticize the university. Gremialistas and monetarist economists then shook their ties for a common goal of depoliticize not only the polity, but also the economy (see Gárate 2012, chapter 3). the possibility of connecting with the Pinochet regime ${ }^{4}$. Guzmán then became the main author of the 1980 Constitution, the institutional instrument that came to seal the neoliberal transformation.

Driven by monetarist orthodoxy, and empowered by extraordinary political control, Pinochet's ministers were able to experiment in the creation of new markets (Farías 2014) - e.g. in education, housing, health, and pensions. Chicago economists not only guided the privatizations but also converted the economic profession to a monetarist approach, becoming the new referent of the emerging business class. They colonized the economics departments of major universities, standardizing the discipline according to the theories of Friedman and Harberger. PUC economists carried out a 'cleansing operation' of public universities, replacing traditional economics scholars - mainly cepalinos - with monetarists (Mönckeberg 2009, p. 154). As the economist Ricardo Ffrench-Davis explains: "the neoliberal ideology is much more intense in Chile than in Argentina, Mexico or Brazil. Seventeen years of Pinochet, the takeover of the universities and the purge of economic faculties were crucial for the conversion of the business associations to neoliberalism" (Interview, November, 2008). The neoliberal 'crusade' was made even more effective because PUC economists also formed and/or acquired several private universities from 1981 onwards, when higher education itself was recast as a new private market (Mönckeberg 2005; 2007).

In contrast to the Chilean case, early U.S. efforts to transform the economics profession in Argentina failed. Cuyo and CEMA, the institutions that embraced Chicago economics, had shorter intellectual and political relevance than PUC in Chile. The largest and most important university in Argentina is the politicized Universidad de Buenos Aires (UBA), where monetarist ideas were contested on ideological grounds, and failed to penetrate its school of economics (Fridman 2010). Despite assistance from private U.S. foundations, the economics profession in Argentina remained committed to structuralism in the 1970s and 1980s. Biglaiser (2009, p.91) argues that a lack of desirable full time academic positions resulted in fewer U.S. educated Argentinean economists holding academic jobs. Many such economists decided to work for international organisations overseas. Without these U.S. trained academics returning to Argentina, students were more likely to enrol in courses taught by professors who opposed monetarist ideas.

In addition, the economic establishment in Argentina did not create a cohesive technocratic team before the coup (Heredia 2004; Canelo 2004). The economists that led El Proceso (1976-1983) were recruited from the liberal think tanks CEMA, FIEL, and Mediterranea (Heredia 2004). The recruitment, however, brought in a diverse and heterogeneous staff. Internal disputes between traditional and technocratic liberals were difficult to reconcile within the team, which consequently lacked the internal coherence needed to influence the military regime. The different branches of the Junta, in addition, also had different priorities for governing (Canelo 2008). Despite the conditions of impunity under the dictatorial regime, there was no dominant actor able to propel marketization in any broadly significant way.

Further, there was no explicit practical reform programme to lend coherence to market reforms in Argentina, whereas Chile had what was called 'the brick' This master document helped to diffuse a coherent ideological agenda, effectively levelling divergent liberal opinion (Valdés 1995; Boisard \& Heredia 2010). The brick was based on two main ideas. First, it advocated 'rebuilding the country', which involved the retrenchment of social expenditure and opening the economy (i.e. liberalization of banks and commerce). Second, it aimed at 'modernization', which focused on seven central areas: labour markets, so- 
cial security, education, health, regionalization, agriculture, and justice. In all of these domains, modernization was based on a series of common principles: decentralization, privatization, free-choice, and competition (Foxley 1987). The business media in Chile strongly supported the diffusion of the 'brick' and liberal ideas in general. El Mercurio, in particular, promoted Chicago measures, emphasizing the reduction of inflation as a remarkable achievement at the end of the 1970s (Montecinos 2009). Over time, the brick became the most prodigious justificatory device of Chilean capitalism, strongly influencing the mindset and identity of the local business class (Tironi 2013). In Argentina, by contrast, there was no such enthusiastic press response to neoliberal ideas, nor a singular programmatic expression of them (Novaro 2006). Despite the existence of traditional newspapers such as La Nación, it was only with the creation of the newspaper Ámbito Financiero in 1977 that pro-market ideas became more widely available to the public in Argentina (Ruiz 2005). The capacity of Ámbito to change popular economic thinking, however, was limited.

III.4. Monetarist policies were eventually rejected in both countries for causing economic collapse, but whereas Pinochet's regime resisted the social pressure, the Malvinas defeat buried both the military and neoliberalism in Argentina

The massive bank run and financial collapse in Argentina in 1980 and in Chile in 1982 were both considered crises of neoliberalism, stemming from a lack of financial regulation and inappropriate macroeconomic policies. Levels of GDP dropped, unemployment and poverty increased, and income distribution worsened (CEPAL 2010). As a reaction to economic collapse, monetarist policies were rejected in both countries, and both their finance ministers Martínez de Hoz and De Castro - were replaced. But while the Pinochet regime, fortified by the recently approved 1980 Constitution, resisted the protests and social upheavals of 1983-1986, the economic collapse in Argentina coupled with the Malvinas military defeat destroyed not only the reputation of the military but also that of liberal market reform. Market policies in Chile started to gain acceptance among businesses and the political class only after 1985, with the economic recovery.

Pinochet's regime was neither a monolithic unit nor a coherent programme from beginning to end. Historical accounts of the regime tend to consider three internal stages (Ffrench-Davis 2007). First, the establishment of military order (1973-1974); second, neoliberal reforms in their purest ideological stage - until the bank collapse (1975-1982); and then the pragmatic period that marked the second wave of privatizations (1983-1989). The 1982 banking collapse in Chile produced huge social costs (GDP declined by $13.6 \%$ and unemployment rose to $25 \%)$. Cacerolazos and popular protests, however, were resisted by the regime and dissent was repressed. A series of state interventions that deviated from Chicago policies were promoted by the regime after the 1982-1983 crisis, including tariff increases and selective export incentives, regulation of financial markets, and the take-over of collapsed private banks, which were later privatized again (Kurtz 2001; Ffrench-Davis 2010). Policy-makers from the regime thus seemed to have experienced an institutional learning during the period, loosening ideological commitments to neoliberalism in favour of pragmatic approaches (Montero 1993).

The first attempted neoliberal experiment in Argentina (1976-1983) was more contentious. In addition to the ideological differences inside the Junta, market reforms met strong resistance from Argentina's large industrial sector which historically had depended heavily on the state (Castellani 2009). As mentioned earlier, Martínez de Hoz concentrated on reforming trade policy, exchange rate policy, and the financial system. His deregulation programme 
involved a plan of monthly decreasing devaluations - la tablita - aimed at controlling the exchange rate and reducing inflation. Although this programme generated access to 'easy money', monetarist policies collapsed with the ruinous run on banks and the substantial devaluation of the peso in 1981. The social reaction to the economic crisis and to Argentina's demoralizing 1982 defeat in the Malvinas war was massive, leading to the discrediting of monetarist policies among many other outcomes.

Following the dictatorship and the Malvinas war, the country emerged battered by high levels of public debt and rampant inflation. The democratically elected government of Raúl Alfonsín (1983-1989) prosecuted the Junta members in an effort to restore justice (Pucciarelli 2006). Alfonsín promoted a return to heterodox economic policies, and sought to re-launch the 'productivista' model. In short order, however, his policies led to economic disaster, with inflation rising over 600 percent and external debts climbing to near US $\$ 50$ billion at the end of his tenure (World Bank 2002). Argentina became an icon of the "lost decade" of the 1980s in the region. Successive strikes, economic stagnation and the 1989 hyperinflation crisis destabilized Alfonsín's government, preventing him from completing his term.

In short, while the Chilean military experiment in the end (after 1985) was economically successful, helping to restore class power and forcing the opposition to negotiate with it to ensure transition to democracy, the military government in Argentina could not re-equilibrate the economy in crisis and lost a disastrous war, debilitating their credibility and that of market policies. Due to a legacy of deep economic crises, human rights violations, and the weakness of state institutions, the Argentinean transition to democracy was threatened by serious problems of governance.

III.5. Neoliberal restructuring proceeded further under Pinochet and was then tempered under Concertación, whereas Washington Consensus policies were fully implemented by Menem though they never met with widespread support

In the mid 1990s Argentina and Chile seemed to be on equal footing. In virtue of stabilizing inflationary threats and positive economic results following the reforms, both countries were considered 'poster children' of Washington Consensus policies. Despite the shared optimistic narrative that held sway at this juncture, neoliberalism had very different roots in these countries, as the above discussion indicates. By the 1990s, market reforms in Chile had already experienced almost a decade of adaptation, during which time the social costs of the reforms had been effectively supressed. Marketization in Argentina, by contrast, was being freshly negotiated between Menem's Peronist government, unconvinced industrialists, and a strong union movement. The proposed 'adjustments' met with group resistances.

The Pinochet dictatorship undertook far-reaching reforms in conditions of political impunity, imposing social discipline not only on the working classes, but also on the business sector. The Chilean dictatorship was neither compelled to negotiate compensatory measures with manufacturing firms nor with unions. In fact, it harshly repressed the latter (Winn 2004). Sectoral readjustments were left to the market, and neoliberal restructuring proceeded further, weakening collective forces (M. Taylor 2006). By contrast, the paths of adjustment in 1990s Argentina were guided by a corporatist arrangement covering many industrialists and unions. Menem's government built specific coalitions for each policy and pushed reform to distinct degrees in different industries, depending on the strength of the resistance $-e . g$. the automobile, steel, and petroleum sectors (Etchemendy 2011). The state compensated protected actors in labour and business through market share compensation, or via direct rent allocations 
(Azpiazu \& Basualdo 2004). Those chiefly affected by marketization in Argentina had both the resources and institutional means to pressure political authorities into negotiating their reforms.

To be sure, the continuity of market-friendly policies following the Pinochet regime was an important factor in the consolidation of neoliberalism in Chile. When democracy was restored, the Concertación coalition (1990-2010) opted for maintaining the free market model, aiming to counter-balance the 'social debt' accumulated during the dictatorship (Han 2012) by introducing social policies such as labour and tax reforms (Ffrench-Davis 2010). These policies aspired to achieve 'growth with equity'. Although the achievement of their stated aim may be called into question, in practice neoliberalism was tempered, though at the expense of its progressive promises (Garretón 2012). Concertación helped to build a 'social' market economy geared to protecting vulnerable groups while investing in institutions that would help compensate for market deficiencies (E. Silva 2009).

Nevertheless, it is intriguing to ask why a political coalition associated with workers' unions that had democratically defeated the dictatorship by promising social change then became resistant to structural transformation once it was in power. Key ministers of President Aylwin (1990-1994), such as Enrique Correa, argued that Concertación maintained market policies mainly for pragmatic reasons: "rather than being convinced of private solutions at the time, the inherited system was stable. Any structural change that would have risked the emergent economic growth might have threatened our ability to maintain political power" (Interview, January, 2009). In the first fragile years of democracy, President Aylwin offered to seek fairness and justice but only 'as far as possible'. Abandoning hopes for political revenge and preserving the status quo were the conditions for building governance. Minister Boeninger (1990-1994) in particular promoted a demobilization doctrine that stigmatized protest and social conflict. Channelling social demands through private services became an effective way of producing social order, of imposing 'governmentality at a distance' (Foucault 2008). Moreover, the investment of pension funds in market shares lent further relevance to the performance of local firms and stability of financial markets.

Neoliberal policies in Argentina had their own particularities. The drastic reforms that Menem and Cavallo launched with the convertibility plan in 1991 were proposed in the aftermath of the hyperinflation crisis. That crisis represented a serious trauma for Argentines, a deep break with normal life. The sense of economic disaster, the physical insecurity that resulted from widespread looting, and the power vacuum created by Alfonsin's early resignation combined to open a kind of social abyss. According to Novaro (2009, p. 323), the threat of ungovernability that resulted gave rise to a desperate need to adopt any action or plan that would end the crisis. President Menem, in particular, was not particularly convinced of market reforms, but implemented them in an attempt to control hyperinflation as well as to gain access to international capital in the hope of reversing the recession (Pucciarelli 2011). Rather than reflecting any particularly strong ideological conviction, the acceptance of Menem's restructuring plan by the main political actors reflected a desperate wish to stabilize the economy.

The convertibility plan was a 'fixed peg' that included a requirement that every peso issued by the Central Bank must be matched by a U.S. dollar in its accounts. In addition, structural reforms included liberalized trade, labour market deregulation, opening the financial sector to international capital flows, and the privatization of state enterprises (ILO 2008). Between 1991 and 1993, Argentina privatized all of its major public utility services $-e . g$. the national air- 
line and cargo-shipping companies, state-owned manufacturing firms, as well as the operation of railways, waterways, ports, airports, and the national post service, amongst others (Azpiazu \& Basualdo 2004). The speed with which they were privatized, however, meant that deficiencies in design and regulation were rife.

The peculiar shapes that neoliberalism took in these countries is crucial for understanding the divergence in outcomes. Whereas Argentina implemented all the mandates of the Washington Consensus, Chile implemented more selectively. For instance, in 1991 Aylwin government implemented 'encaje' - a system of capital controls that restrict short-term capital inflows. This reduced the vulnerability of the Chilean economy to international economic shocks, such as that represented by the 1997 Asian crisis. Argentina, by contrast, opened its financial markets to short-term investments, in keeping with Washington Consensus orthodoxy. This let Argentina vulnerable to the volatility of international financial markets. In addition, Chile kept its main national industry - the copper mining company Codelco - in state hands, whereas Argentina privatized all its key natural resource industries. While Codelco's revenues continue to finance over $40 \%$ of government social programmes in Chile, social policies in Argentina are mainly financed by state taxation of business revenues. Furthermore, scholars have called into question the idea that Chile's post-1985 export boom was the result of free market policies, arguing that key exporting sectors such as fisheries, forestry, and fruit were consolidated through state support (Kurtz 2001).

III.6. Political technocracy helped build a neoliberal consensus in Chile, while the attempt to disenchant politics by economics was unable to disarm the collective tissue of Peronist's networks in Argentina

Another striking difference between market reforms in Argentina and Chile was the support given (or withheld) by key political actors. Whilst in Chile a technocratic arrangement among political elites in the 1990s helped sustain market-friendly policies, in Argentina no shared conviction supported the pro-business model. Despite policy-makers' agreement on the need to modernize the state, clientelistic practices and competing strategic policies were always present, a diversity of policy perspectives that remains today.

The renovation of centre-left thought was fundamental for the continuity of market-friendly policies in Chile. During years spent in exile or in resisting the dictatorship, many intellectuals renewed their thinking about markets, whether studying abroad or in independent centres in Chile (Puryear 1994). The role of centres such as Cieplan, FLACSO, Ilades, CED and SUR was crucial in shaping the technocratic thinking of Concertación. The group of technocrats that came to power with the Aylwin government, the 'Cieplan Monks', in many respects resembled their neoliberal predecessors, the Chicago boys (P. Silva 1991). The 'technopols', a new type of politician with a technocratic orientation toward economics (P. Silva 2008; Joignant 2011), spread among the political class. As right wing leader Joaquín Lavín points out: “technocracy in Chile is very strong across the whole political spectrum. It was one of the self-imposed missions [of the Pinochet regime]: to create a critical mass of economists that would moderate things" (Interview, December, 2008).

In addition, the political constraints operative during the 'transition to democracy' in the 1990's along with fear of Pinochet himself (who remained in control of the army until 1998), limited public criticism of the economic model. Remaining 'authoritarian enclaves' and 'extra-institutional circuits of power' i.e. the links between the military, business sectors and right wing parties - fur-

5 The major constraints in this respect were represented by ther inhibited the expression of conflict (Cortés Terzi 1997) ${ }^{5}$. While an empowered business class sought to defend the economic model and the legacy of 
the existence of designated senators, the state security council, the binominal voting system and the inability of the President to designate the head of the army. President Lagos reformed most of the 'authoritarian enclaves' in 2005, except for the binominal political election system, a centrepiece of Pinochet's 1980 Constitution.
Pinochet's regime, critical voices within Concertación, which agitated for reform, were dismissed by establishment members of their own government. According to Garretón (2013), Concertación did not have the knowledge, will or power to change the market model. Thus, the transition to democracy was characterized by a pragmatic ethic, gradualist change, and the large-scale acceptance of the country's extant political norms. The political practices that facilitated the transition to democracy were based on tacit agreements among political and economic elites, marginalizing those who sought to question the neoliberal order (Fuentes 2013). During the Concertación and Piñera governments (1990-2014), demands for increasing social expenditure were effectively contained by the priority of fiscal discipline. The powerful Ministers of Finance of these administrations - i.e. Foxley, Aninat, Eyzaguirre, Velasco, and Larraín - kept economic order as their main priority.

In Argentina, the changing nature of Peronism was crucial to both enable and limit neoliberal restructuring. On the one hand, the transformations of the Justicialist Party (PJ) during the 1980s and the 1990s were instrumental in enabling the deployment of market reforms. According to Levitsky (2003, pp.107-143), during the 1980s PJ ceased to be a party dominated by traditional labour unions, and instead shifted toward patronage networks, especially in poor neighbourhoods. The dismantling of the traditional mechanisms of labour participation, and the consequent erosion of syndicalist influence, eliminated key sources of domestic opposition to Menem's reforms. On the other, compensation and clientelistic networks administered by Peronist political brokers (punteros) in popular neighbourhoods remained vital to maintaining political mobilization (Auyero 2007). The Peronist philosophy of popular participation continued during the 1990s and reproduced practices that were in many ways incompatible with the attempt of neoliberalism to disenchant politics by economics.

The implementation of market reforms in 1991 also coincided with a preponderance of economists in public affairs and public decision-making (Heredia 2008). Those economists, however, had to deal with a diverse political class that included union members, regional leaders, and traditional politicians. Technocracy in Argentina never had the hegemonic position that enjoyed in Chile. Voices of dissent continued to be heard in the mainstream press, and at the end of the decade, Argentineans had a polarized view of the 1990s model. Whilst government advocates stressed that Argentina had 'entered the first world', critics denounced the 'latin-americanization' of the social structure (idem, p.205). During the recession years of 1998-2002 the model's promise waned further, eroding the hopes of the neoliberal project.

III. 7. Neoliberalism produced different outcomes and knock-on effects: whereas material progress spread a notion of success in Chile, the 2001 implosion extended disenchantment in Argentina, triggering a backlash against marketization

The distinctive experiences of neoliberalism in Argentina and Chile lent capitalism itself different popular legitimacies in each country. While capitalist modernization in Chile, with its emphasis on private property and individual rights, brought material progress in a context of inequality, the few modernised aspects of 1990s Argentina were crushed by the social, political and economic implosion of 2001, burying any positive popular feeling about market reforms.

Chilean society changed significantly under market reforms. Between 1990 and 2010, its GDP tripled, and the proportion of its population living below the poverty line fell from $40 \%$ to $15 \%$ (Chile 2011). In the last three decades Chilean quality of life improved along a number of axes: quality of housing, home equipment, access to education, and basic services (Atria et al., 2013, p.259). 
The expansion of markets and of popular credit effectively 'democratized' consumption across new sectors, creating new citizen-consumers (UNDP 1998). Access to tertiary education as well as private debt grew exponentially during this time, as the number of private universities multiplied. While optimistic readings celebrate the expansion of the Chilean educational system, in which 70 per cent of university students are first generation, critics emphasize the perversion of a profit-oriented system that in many respects still reproduces social inequalities (Mayol 2012).

Economic expansion also gave the private sector and the business class a hegemonic position, which has been further bolstered by a triumphalist narrative about the country's progress (Larraín 2001). Occupying a leading position in economic regional rankings, and being included in the OECD has reinforced this celebratory vision. President Piñera's government (2010-2014) sought to capitalize on this spirit, extending private sector norms and practices to public institutions and boasting of a style of governance modelled on corporate management.

Despite the clear economic advances it has wrought, neoliberalism has been subject to intense scrutiny in Chile, especially after the 2011 revolts and the rise of the ensuing social movements. In the late 1990s, the market model received both "complacent" and "self-flagellating" readings from inside Concertación. While the former emphasized the country's prosperity and the stability of the economic model (Tironi 1999; Larraín \& Vergara 2000), the latter accentuated distributive inequalities, and the inability of Concertación to achieve "growth with equity" (Moulian 1998; Garretón 2012). These discrepant readings again resurfaced in the aftermath of Concertación, when party members sought to come to grips with its legacy. For some, Concertación was able to achieve social democracy as far as was effectively possible, for the latter, Concertación managed, at best, to give neoliberalism a human face (Atria 2013). The eruption of social movements has stimulated discussion of the country's economic model, with scholars calling for the launch of a new social democratic model (Atria et al., 2013).

Market reforms in Argentina produced an even more controversial result. On the one hand, the convertibility plan successfully stabilized the economy, achieving a rapid reduction of inflation and interest rates. Output soared between 1991 and 1997. The business sector grew quickly and multinational corporations took hold in several new industries. On the other hand, many national industries, accustomed to tariff barriers and protections, could not cope with international competition, and closed. Significant job losses resulted and unemployment grew to $19 \%$ in 1995 (Novaro 2006). Privatized enterprises, mainly administrated by foreign corporations, boasted profit margins much higher than those obtained by nationally owned businesses, generating charges of global exploitation and injustice (Azpiazu \& Basualdo 2004). After the consumerist boom of the first few years, a rise in poverty and social inequality also became evident. The 'new poor' (Minujin \& Kessler 1997) became increasingly visible in public spaces. The neoliberal program produced a reconfiguration of the power structure, strengthening the economic elite at the expense of worker's safety. As Canelo et al. (2011, p.16) suggest, the 1990s in Argentina "synthesized, in its way, a sudden integration into economic globalization and technological leap of the late twentieth century, with a falling to unprecedented levels of deprivation in the country and widespread practices of wage exploitation and political domination no less regressive". Menem finished his second term (1994-1998) with his reputation in tatters. The piquetero movement - led by unemployed former state enterprise functionaries, such as YPF, among others became the new symbol of social malaise. 
At the turn of the new century, social pressure looked set to implode neoliberalism in Argentina. Social movements calling for protection against market expansion (Polanyi 2001) grew sharply; pickets, roadblocks, and protests multiplied among those who felt they had been damaged by neoliberal modernization (E. Silva 2009; Villalón 2007). The crisis exploded in December 2001, when order broke down in the provinces as people began to loot stores in Rosario, Mendoza, Entre Ríos, and Buenos Aires. Simultaneously, the imposition of 'corralito' provoked discontent among the middle classes. Widespread protests arose against De la Rua's government. Buenos Aires, famously, became the scene of street battles. 'Que se vayan todos!' (Let's get rid of them all!) was the cry on the streets, calling for the ouster of the ruling political classes. Between 20th December 2001 and 2nd January 2002, Argentina had five presidents. It seemed all but impossible to contain the turmoil, until Peronist Eduardo Duhalde restored political power, managing to bring the situation under control.

Argentina stopped making payments on its foreign debt, officially defaulting on US $\$ 132$ billion. In January 2002, the convertibility plan came to an end. After 11 years, the peso-dollar peg was scrapped. The peso was left to float and suffered a sharp devaluation, losing about $70 \%$ of its value in four months (Levi \& Valenzuela 2007). As a consequence of four years of recession (1998-2002) and the implosion of 2001, poverty became severe. In October 2002, INDEC revealed that $57.5 \%$ of Argentineans were living below the poverty line and $27.5 \%$ were in extreme poverty. The Argentinean population was not only impoverished but also lost faith in its institutions and authorities. The credibility of the political and business classes was completely shattered.

The question of what went wrong became pressing in the wake of the 2001 crisis. For some commentators the crisis was due to a lack of neoliberalism. According to this view, the government was unable to 'discipline' federal administrations and union demands, thereby increasing the fiscal deficit. For others, the crisis was due to an excess of neoliberalism. In this view, the devastating social consequences of high unemployment and polarizing inequality were an unstoppable time bomb. Democratic Argentinean society was not ready to pay the transitional social costs that Chile eventually did under conditions of dictatorship. Further, the taint of corruption that hung about the privatization process also undermined its legitimacy. The modernizing improvements the process partly delivered were lost under the massive social costs it imposed. Even for the ideologists of the convertibility plan, such as Juan Llach, the results were appalling. In his own words, "[Neoliberalism in Argentina] is in a double crisis. First, it is the real crisis. It produced a profound social crisis and a recession that lasted four years. Then, there is the ideological crisis: neoliberalism lost its anchor and social validity" (La Nación, September 13, 2003).

III.8. Neoliberalism as a de-collectivising project advanced further in Chile - particularly in the workplace, whereas in Argentina's post-convertibility landscape the Kirchners reinvigorated faith in politics and collective organization

A critical factor shaping the divergent fates of neoliberalism in these countries is the degree to which their societies were de-collectivized through market reforms. Whereas the mix of privatization and regulatory constraints on collective action effectively restrained Chilean society during Concertación years (1990-2010), similar attempts at popular deactivation did not succeed in Argentina. By contrast, the post-2001 reaction and the counteroffensive lead by the Kirchner's governments (2003-2015) revitalized collective forces and the spread of social movements. Contrasting current labour rights and conditions as well as the status of unions reveals the extent to which the situation diverges in the two countries. 
Organized labour in Argentina has a robust history. The collective rights achieved during the Perón years (1946-1955) resulted in the labour movement gaining significant industrial and political power. The Argentine labour movement was incorporated into the party political system by becoming the structural, ideological, and financial base of Peronism (Atzeni, Durán-Palma \& Ghigliani 2011). As mentioned earlier, the reforms lead by Menem's governments (1989-1999) had a profound impact on the labour market (unemployment reached $19 \%$ in 1995). Labour unions were weakened as centralised collective bargaining was limited to firm level in a bid to facilitate flexibility and economic adjustment, especially in the newly privatised utilities and enterprises. In exchange for introducing reforms - and a way of co-opting the CGT (Confederación General del Trabajo) -, the Menem governments allowed unions to invest in the new business opportunities brought about by the privatisation of pensions, labour accidents insurance and health care (idem, p.142). For a country accustomed to high labour participation, unemployment was experienced as a qualitative loss of citizenship.

In the aftermath of the 2001, both Kirchner governments promoted a backlash against free market economics. Stimulated by the boom of commodities, Argentina embarked on a period of economic recovery and debt renegotiation. The post-neoliberal Kirchner governments launched a litigant style of politics that promised social justice through robust government intervention in the economy and society (and the National Institute of Census and Statistics INDEC). They not only strengthened state institutions, but also empowered collective organisations, i.e. unions, human rights associations and the Justicialist party. A resurgent formal union movement grew, led first by informal workers and more recently by union representatives from relatively privileged formal sectors, e.g. subway, auto, oil, and tyre workers (Etchemendy 2010). Centralised wage bargaining in industrial and service sectors, and agreements on sector-wide wage increases as well as the minimum wage represent a backlash against the labour flexibility of the 1990s. The number of collective agreements increased from 348 in 2004 to 1,231 in 2008. Despite unions' proportionally diminished number of members, union density among unionised workers remains at $40 \%$ (Atzeni, Durán-Palma \& Ghigliani 2011). Likewise, union bargaining among formal employees in Argentina was over 70\% in 2007 (ILO 2008), which is a considerable number in the Latin American context.

The optimism generated over the course of the Kirchner administrations, and the death of Néstor Kirchner in October 2010, help to explain the 53 percent popularity with which Cristina Fernandez de Kirchner was re-elected in 2011. The revival of militant street protest among young people is another sign of the revitalization of politics in Argentina (e.g. La Campora led by Máximo Kirchner; Jóvenes K; JP Evita; los Guardianes de la Democracia; 25 de Mayo; Perukas; Oktubres) (Pavón 2012, p.553). According to the Barometer of the Americas 2010 (Lodola 2011), Argentina stands out for being one of the most confrontational countries in the region, where social protest is seen as an efficient means of achieving political aims. The proportion of Argentines that demonstrated in the streets in 2010 was vastly greater than the proportion of those who participated in institutionalised conflict resolution channels, such as petitioning legislators, mayors or councillors - this reflects, among other things, the considerable public legitimacy street demonstrations have in Argentina.

Argentina's still robust trade union culture, contrasts strongly with the situation in Chile. The atomised labour movement there has its own history. During 17 years of dictatorship (1973-1990) unions were politically repressed and their leaders 'disappeared' (Cavallo, Salazar \& Sepúlveda 1988). The collective rights achieved through Peronism in Argentina were exactly what José Piñera, Pinochet's Minister of Work, sought to avoid through the 1979 Labour Code in 
Chile (Piñera 1990, p.58). Prohibiting the unionisation of temporary workers and public servants, limiting strike days, and giving free rein to firms to dismiss workers for 'business reasons', all undermined collective action, seriously transforming the power balance between capital and labour. Collective bargaining was allowed only at individual firm level, reducing any form of sectoral or national negotiation. Employer's capacity to depress wages while increasing both workloads and the length of the working day helped Chilean capitalism to boom in the 1980s. According to Winn (2004), the working class and its organisations were the main victims of the 'Chilean miracle'.

Although the 1983-1986 cycle of mobilizations activated Chilean society, the labour movement was so structurally debilitated by the dictatorship that it was unable to organise resistance against neoliberal reforms. Concertación (1990-2010) then also helped to demobilise labour in the interest of promoting governability. Although Concertación promised to re-balance power between workers and firms ("there is no democracy without labour reform"), the changes in the labour code (1990, 1993, 2001 and 2006) were unable to reduce social disparities, which remained virtually unchanged between 1990 and 2010 (Gini 0.56 to Gini 0.53). Despite consecutive labour reforms, the balance of power remains clearly angled in favour of firms. Almost two thirds of the Chilean labour force is working on short-term contracts or under other conditions of precariousness (Sehnbruch 2009, p.8). The number of contracts of indefinite duration has had a steady decline (49.5\% of the workforce in 1998 to 41.5 in 2012) (Fundación Sol 2013). Vulnerable employment has proliferated in successful sectors such as mining, fishing, retail, and agricultural exports through subcontracting, which allows companies to outsource their work responsibilities (Echeverría 2010; Stecher 2013). Union density and the incidence of collective bargaining have also shrunk considerably. While the unionization rate nationwide was $21.1 \%$ in 1991, in 2010 it was only $15.8 \%$ (Chile 2011a), with the highest figures in the mining sector. Similarly, the percentage of workers involved in collective bargaining fell from $10.3 \%$ in 1991 to $6.8 \%$ in 2009 (Chile $2011 \mathrm{~b}$ ). The participation of workers in strikes is also minimal. While in 1991, $1.5 \%$ of employees that can potentially bargain collectively participated in a strike; in 2012 the figure reached only $0.65 \%$ (Durán 2013, p.90).

Chile's profound structural inequalities, however, have meant that different vulnerable groups have become more likely to agitate. Growing strikes and protests by contract workers in the mining, forestry, and retail sectors $(2006,2007$ and 2011) reflect permanent tensions between workers, contractors and large firms (Durán-Palma \& Lopez 2009; Echeverría 2010). The 2011 protests, in particular, mark a breaking point in this regard. Both the students on the streets, and the public in surveys, voiced opposition to private, for profit education, and the high levels of individual debt that go with it. This widespread expression of discontent has constituted a significant challenge to the neoliberal model. The belief that collective organization and protesting in the streets may affect politics has risen firmly in recent years, evincing new hopes for social change.

III.9. Whereas business elites have constantly defended the capitalist modernization in Chile, renewing its justifications, the counter-offensive lead by the Kirchners and allies had further weakened neoliberalism in Argentina

A further factor differentiating neoliberalism's fate in Argentina and Chile is the role of the capitalist class. Neoliberalism partly succeeded in Chile because the bourgeoisie, the strata destined to defend capitalism (Schumpeter 1976), was empowered by the market reforms, and, consequently, was better able to protect and justify the new market model. This did not come to pass in Argentina, where the dispersed business class never rose to such power, and 
were perceived as accomplices in the 2001 crisis. While divisiveness and internal competition have undermined the capacity of the Argentine business sector to build a common agenda, the politically connected capitalist class in Chile has been largely effective in defending a pro-business environment, at least until recently.

Business associations in Chile, gathered under the umbrella of the Confederation for Production and Commerce (CPC), are powerful actors with significant capacity to coordinate divergent sectors (e.g. agro-business, banks, mining, or industry). Further, informal networks based on family relations, religious groups, college mates, chains of capital, and shared business interests connect economic elites (Tironi 1999; Thumala 2007). Partisan linkages with Unión Demócrata Independiente (UDI) and Renovación Nacional (RN), the two powerful right wing parties, have facilitated the defence of business interests in Parliament, such as maintenance of low taxation and a flexible labour market (Undurraga 2012). Due to the strong structural power of the private sector, Concertación governments (1990-2010) felt the need to consult with business associations on the details of their reforms. For instance, both Leyes de Mercado de Capitales I y II during the Lagos and Bachelet administrations were based on proposals written by the industrial association SOFOFA. Unsurprisingly, none of the key reforms of the Concertación governments - tax (Aylwin), state modernisation (Frei), health (Lagos) and pensions (Bachelet) were as progressive as they were originally believed to be, achieving only a partial correction of neoliberalism's inequities (Garretón 2012). The power of businesses and the right wing sector - overrepresented in parliament due to the binominal system - constrained further, more progressive policy changes.

Since the mid 1980s, the market model become more explicitly and aggressively defended by the private sector itself. Corporations invested in business associations and institutions that celebrated the economic success of the 'exporter model' and promoted free market values. These institutions formed what Thrift (2005) calls 'cultural circuits of capitalism', based on strong networks of enterprises, pro-business organisations, think tanks, private universities, and the economic media (Undurraga 2013). These business circuits have renewed the justifications of Chilean capitalism, integrating and effectively transforming the criticism it has received - e.g. corporate social responsibility discourse in mining industry (Tironi \& Zenteno 2013). Different business centres such as ICARE and CEP, plus strong business associations play a key role in promoting a business agenda, offering technical support for regulatory lobbying in the Parliament. The election of businessman Piñera as Chilean president (2010-2014) was the crowning triumph of the new managerial elite, which was not only enriched by capitalist modernization but acquired the political authority to go with it.

It is interesting to note, however, that the increasing awareness of Chile's structural inequalities has started to erode the unchallenged position of business. Different groups have become more likely to agitate for the improvement of their social conditions (Undurraga 2014). The Piñera administration's links with the business class aroused suspicion that the government was far too beholden to business interests. Complaints against a profit-driven university system, corporate scandals involving price-fixing pharmaceutical retailers and unilateral renegotiation of unpaid debtors banks (e.g. La Polar, Cencosud) all increased this sense of discontent. According to a UDP 2011 National survey, between 2010 and 2011, confidence in large companies declined from $27.9 \%$ to $16.5 \%$.

The situation is starkly contrasting in Argentina. Business associations do not have the capacity to influence governance at industry level to anywhere near 
a comparable degree. Different factions defend their own business strategies, strengthening their particular political ties and promoting their own, often competing, economic interests (Lewis 2009). Despite the existence of several business associations, such as SRA (Sociedad Rural Argentina), UAI (Union Industrial Argentina), and ADEBA (Asociación de Bancos Argentinos), there is no single encompassing business association like the Chilean CPC. This situation is not new. Agriculture and industry in Argentina developed strong associations before Perón, but rivalry and the politicisation of business representation by Peronism increased fragmentation among the business sector (Acuña 1998). Despite several attempts to build an economy-wide peak association, the inability to reconcile sectorial interests, and weak institutional capacity undermined these efforts (Schneider 2004).

Under the Kirchner governments (2003-2015), pressure on the private sector grew steadily, with only businessmen close to the government exempt from interference (for a full picture of the business groups favored and disfavored during the Kirchner years, see Gaggero, Schorr \& Wainer 2014). International corporations, firms linked to the government opposition, and the agro-industrial sector, in particular, criticize the 'hostile' business environment installed by the Kirchners. During their governments, public service contracts with privatized utilities were renegotiated, AFJP - the private pension system - Aerolíneas Argentinas and YPF (Petroleum) were re-nationalized, and television cable contracts were negotiated anew. The Kirchners also increased taxes on commodity exports, such as soybeans, meat, and wheat. For example, the 2008 conflict between the government and the farm industry over hikes in export taxes (retentions) crisped the political environment. Conflicts with the adversaries to their post-neoliberal politics increased, reinvigorating political life.

The credibility of the business class - alongside politicians and unions - is widely doubted in Argentina. Their capacity to defend a business agenda and to justify their way of doing business is also limited. Corruption, low patriotism, and tax evasion are accusations commonly levelled at economic elites. Successful entrepreneurs in Argentina tend to keep a relatively low profile. With the exception of the business media, they do not frequently appear in the public press commenting on current affairs. Businessmen interviewed for this study commented that it is not convenient for them to show off their success or to be too loud in defending their interests in the public domain. Alfredo Coto, for instance, owner of a supermarket chain and president of the business association IDEA, gave an interview on November 18, 2005, before IDEA's annual meeting, criticising the government and projecting 13\% inflation for 2006. The Kirchners reacted ferociously, applying significant political pressure to $\mathrm{Mr}$. Coto who ended up renouncing the presidency of IDEA. He was subsequently the first employer to sign a price agreement with the government. José Miguel Aranguren, the president of Shell, endured a similar experience in 2005 after challenging Kirchner's call to boycott Shell because of their refusal to accept government imposed price limits. Consequently, many businesses have been subjugated by the political power of the Kirchners, with the exception of some business friends of the government who have maintained privileges - to an extent.

\section{Conclusions: post-neoliberalism in Argentina and Chile?}

Some scholars argue that Argentina entered a phase of post-neoliberal politics in the last decade (Riggirozzi 2010; Grugel \& Riggirozzi 2012). The counter-reaction against market policies canalised by the Kirchner governments echoes the double movement of social protection Polanyi describes (1944). The Kirchners reinforced the activation of popular actors and enhanced the legiti- 
macy of the state's right to intervene in structuring economic affairs. Further, they installed a narrative of a "before and after", where before was neoliberalism and the 2001 crisis, and after were economic recovery and the restoration of memory and national pride. These changes have certainly generated their share of conflicts; disputes about the proper relationship between the state and the private sector remain lively (Undurraga 2014).

Despite the emphasis on a post-neoliberal narrative, it is important to stress that the Kirchner governments have maintained some continuities with the neoliberal slogans of the 1990s, for instance they have largely preserves the fiscal equilibrium. While their macroeconomics took a Keynesian turn, stimulating internal consumption, at the microeconomic level the restructuring ethos of neoliberalism (Peck, Theodore \& Brenner 2009) remains alive at least in some areas. Many Argentineans prefer private services over state provided ones when it comes to education, health, and security, even in the lower-middle classes. On the other hand, although the Kirchners succeeded in restoring broad confidence in state institutions, a number of outstanding problems continue to plague Argentinean society, such as insecurity and fear of crime, inflationary pressures, and deteriorating public services in health, education, and transport (Kessler et al., 2010). In between these breaks and continuities, conflicts between supporters and opponents of the Kirchner project have gained new impetus. While the government spreads its incendiary rhetoric against global financial institutions, 'vulture' funds and anybody else that threatens the social achievements of the national-popular model, the opposition criticizes the rising inflation, state intervention in manipulating national statistics (INDEC) and the absence of international financial credit, calling for an end to the "capitalism of friends".

In Chile, the rise of the 2011 mobilizations seems to mark the beginning of a new political cycle. Some argue that a post-neoliberal order may be emerging, an order that calls into question the core of the neoliberal model, i.e. the disenchantment of politics by economics. The three promises of President Bachelet's programme (2014-2018) - free education for all, tax reform and a new democratic constitution - aimed to respond to this new political cycle, moving away from orthodox neoliberalism towards a more social democratic model. Despite the commitment of Bachelet's coalition (Nueva Mayoría) to carrying out structural reforms, and despite the support Bachelet herself received at the ballot box $(62 \%)$, passing these reforms in the congress have not - thus far - been easy.

Six months into Bachelet's administration, differences have emerged that distinguish the current government from what came before, though the shift has not been as marked as some expected. A tax reform was effectively approved in July 2014, raising corporate income tax from 20 to 25\%, though the package approved was substantially less progressive than the original. Rather than including any social movement representatives at the negotiation table, the final agreement was hammered out between the government and the opposition at the house of a business representative (Peña 2014). Thus, the same elite style of politics characteristic of the old Concertación was manifest, evincing that although the power of the business classes might have been challenged, in many respects it has not yet been diminished. The education reform is undergoing negotiations with all kinds of 'stakeholders', but the government political capital is shorter than it was in March 2014. Interestingly, the same scholar that interpreted the 2011 student revolts as the 'demise of the model' (Mayol 2012) has recently announced a new book entitled "the demise of the demise" (Mayol 2014). Although it is unclear the extent to which the new political cycle will differ from that of the Concertación years, the effervescence of Chilean society and the belief that collective pressure in the streets can effectively change politics is challenging the technocratic hegemony of recent decades. 
Having said that, it would be hasty and unwarranted to consider the rising mobilizations in Chile as akin to the post-neoliberal reaction that characterised the 2001 aftermath in Argentina. Chile has not had any political or economic crisis on that kind of scale, nor has it experienced a political movement such as Kirchnerism, which has led a counter-offensive against the neoliberal model. Further, after 30 years of adjusting regulations the market model is deeply embedded in Chilean society; the ambivalent decade of Menem's neo-liberal experiment in Argentina produced no such result. As those who likened Chile and Argentina to each other as 'poster children' of the Washington Consensus were proven wrong by history, so too it would be a mistake to draw hasty comparisons between the post-neoliberal impulses at work in these countries today.

Tomás Undurraga (t.undurraga@ucl.ac.uk) holds a PhD in Sociology from the University of Cambridge (United Kingdom) and is presently a postdoctoral researcher in the Department of Science and Technology Studies of the University College London. Institutional Affiliation: University College London, London, United Kingdom.

\section{References}

Acuña, C., 1998. Political Struggle and Business Peak Associations: Theoretical Reflections on the Argentine Case. In F. Durand \& E. Silva, eds. Organized Business, Economic Change, and Democracy in Latin America. Miami: North-South Center Press.

Atria, F., 2013. Veinte años después. Neoliberalismo con rostro humano. Santiago de Chile: Catalonia.

Atria, F.; Larrín, G.; Benavente, J.M.; Couso, J. \& Joignant, A., 2013. El Otro Modelo. Del orden neoliberal al régimen de lo público. Santiago de Chile: Debate.

Atzeni, M.; Durán-Palma, F. \& Ghigliani, P., 2011. Employment Relations in Chile and Argentina. In: M. Barry; A. Wilkinson, eds. Research Handbook of Comparative Employment Relations. Cheltenham: Edward Elgar.

Auyero, J., 2007. Routine Politics and Violence in Argentina. The Gray Zone of State Power. New York: Cambridge University Press.

Azpiazu, D. \& Basualdo, E., 2004. Las privatizaciones en la Argentina. Genesis, Desarrollo y Principales Impactos Estructurales. In J. Petras \& H. Veltmeyer, eds. Las privatizaciones y la desnaciónalización de América Latina. Buenos Aires: Prometeo.

Biglaiser, G., 2002. Guardians of the Nation? Economists, Generals, and Economic Reform in Latin America. Notre Dame: University of Notre Dame Press.

, 2009. The Internationalization of Ideas in Argentina's Economics Profession. In V. Montecinos \& J. Markoff, eds. Economists in the Americas. Northhampton: Edward Elgar.

Boisard, S. \& Heredia, M., 2010. Laboratoires de la mondialisation économique: Regards croisés sur les dictatures argentine et chilienne des années 1970. Vingtième siècle, revue d'histoire, 105, pp.109-125.

Camargo Brito, R., 2008. El Carácter Traumático del Consenso en torno al Modelo Chileno: Una Investigación sobre la Elite Política Democrática Post-Pinochet. In Maite de Cea, P. \& Díaz, G.K., eds. Chile: ¿De país modelado a país modelo? Santiago de Chile: LOM.

Canelo, P., 2004. La política contra la economía: Los elencos militares frente al plan económico de Martínez de Hoz durante el Proceso de Reorganización Nacional (1976-1981). In: A. Pucciarelli, ed. Empresarios, tecnócratas y militares: La trama corporativa de la última dictadura. Buenos Aires: Siglo XXI. 2008. El Proceso en su laberinto. La interna militar de Videla a Bignone. Buenos Aires: Prometeo.

Canelo, P.; Heredia, M.; Gené, M. \& Sosa, P., 2011. Introducción: Perplejidades y persistencias del peronismo durante los años noventa. In: A. Pucciarelli, ed. Los años de Menem. La construcción del orden neoliberal. Buenos Aires: Siglo XXI.

Castellani, A., 2009. Estado, empresas y empresario: La construcción de ámbitos privilegiados de acumulación. Argentina 1966 -1989. Buenos Aires: Prometeo.

Cavallo, A.; Salazar, M. \& Sepúlveda, O., 1988. La Historia Oculta del Régimen Militar. Santiago de Chile: Editorial Antártica.

Centeno, M. \& Silva, P., eds., 1998. The Politics of Expertise in Latin America. New York: Palgrave Macmillan.

Cortés Terzi, A., 1997. El circuito extra-institucional del poder. Santiago de Chile: América-Cesoc.

Crouch, C., 2011. The Strange Non-Death of Neoliberalism. London: Polity Press.

Crozier, M.; Huntington, S. \& Watanuki, J., 1975. The Crisis of Democracy: Report on the Governability of Democracies to the Trilateral Commission. New York: New York University Press.

Davies, W., 2014. The Limits of Neoliberalism: Authority, Sovereignty, and the Logic of Competition. London: Sage Publications.

Dezalay, Y. \& Garth, B., 2002. The Internationalization of Palace Wars. Chicago: The University Chicago Press.

Donoso, S., 2013. Dynamics of Change in Chile: Explaining the Emergence of the 2006 Pinguino Movement. Journal of Latin American Studies, 45(1), pp.1-29. 
Dumenil, G. \& Levy, D., 2004. Capital Resurgent: Roots of the Neoliberal Revolution. Cambridge, MA: Harvard University Press.

Durán, G., 2013, Panorama Sindical y de la Negociación Colectiva en el Chile de los US\$22.655. Revista de Derecho y Seguridad Social, 3, pp.85-96.

Durán-Palma, F. \& López, D., 2009. Contract labour mobilisation in Chile's copper mining and forestry sectors. Employee Relations, 31(3), pp.245-263.

Echeverría, M., 2010. La historia inconclusa de la subcontratación y el relato de los trabajadores. Santiago de Chile: Dirección del Trabajo, Gobierno de Chile.

Etchemendy, S., 2011. Models of Economic Liberalization. Cambridge, UK: Cambridge University Press.

Etchemendy, S. \& Collier, R.B., 2007. Down but not out: The Recovery of a Downsized Labor Movement in Argentina (2002-2007). Politics and Society, 35(3), pp.363-401.

Fairfield, T., 2010. Business Power and Tax Reform: Taxing Income and Profits in Chile and Argentina. Latin American Politics and Society, 52(2), pp.37-71.

Farías, I., 2014. Improvising a Market, making a Model: Social Housing Policy in Chile. Economy and Society, 21, pp.346-369.

Ffrench-Davis, R., 2007. Entre el neoliberalismo y el crecimiento con equidad: Tres décadas de política económica en Chile. Santiago de Chile: LOM.

2010. Economic Reforms in Chile: From Dictatorship to Democracy. New York: Palgrave Macmillan.

Foucault, M., 2008. The Birth of Biopolitics: Lectures at the College de France 1978-1979. New York: Palgrave Macmillan. Foxley, A., 1987. Chile y su futuro: Un país posible. Santiago de Chile: Cieplan.

Fridman, D., 2010. A New Mentality for a New Economy: Performing the Homo Economicus in Argentina (1976-83). Economy and Society, 39(2), pp.271-302.

Fuentes, C., 2013. El Pacto: Poder, Constitución y prácticas políticas en Chile (1990-2010). Santiago de Chile: Ediciones UDP.

Gárate, M., 2012. La Revolución Capitalista en Chile 1973-2003. Santiago: Ediciones Universidad Alberto Hurtado.

Garretón, M.A., 2012. Neoliberalismo Corregido Y Progresismo Limitado. Los gobiernos de la Concertación en Chile, 1990-2010. Santiago: Editorial Arcis/Clacso.

Gaggero, A; Schorr, M. \& Wainer, A., 2014. Restricción eterna : el poder económico durante el kirchnerismo. Ciudad Autónoma de Buenos Aires: Futuro Anterior Ediciones.

Grugel, J. \& Riggirozzi, P., 2012. Post-Neoliberalism in Latin America: Rebuilding

and Reclaiming the State after Crisis. Development and Change, 43(1), pp.1-21.

Guell, P., ed., 2009. El Chile que viene: de dónde venimos, dónde estamos y a dónde vamos. Santiago: Ediciones Universidad Diego Portales.

Han, C., 2012. Life in Debt. Times of Care and Violence in Neoliberal Chile. Berkeley: University of California Press.

Harvey, D., 2005. A brief History of Neoliberalism. Oxford: Oxford University Press.

Heredia, M., 2004. El proceso como bisagra. In A. Pucciarelli, ed. Empresarios, tecnócratas y militares: La trama corporativa de la última dictadura. Buenos Aires: Siglo XXI.

, 2008. Entre reflexividad, legitimación y performatividad. El discurso económico en la instauración y crisis de la convertibilidad. Revista Crítica en Desarrollo, 2(2), pp.191-214.

Huneeus, C., 2001. El Régimen de Pinochet. Santiago de Chile: Sudamericana.

Joignant, A., 2011. The Politics of Technopols: Resources, Political Competence and Collective Leadership in Chile, 1990-2010. Journal of Latin American Studies, 43(2), pp.517-546.

Kessler, G.; Svampa, M. \& Gonzalez Bombal, I., eds., 2010. Reconfiguraciones del mundo popular. El Conurbano Bonaerense en la postconvertivilidad. Buenos Aires: Prometeo Libros/Universidad Nacional de General Sarmiento.

Klein, N., 2007. The Shock Doctrine: The Rise of Disaster Capitalism. New York: Picador.

Kurtz, M., 1999. Chile's Neo-Liberal Revolution: Incremental Decisions and Structural Transformation, 1973-1989. Journal of Latin American Studies, 31(2), pp.399-427.

, 2001. State Developmentalism without a Developmental State: The Public foundations of the 'Free Market Miracle' in Chile. Latin American Politics and Society, 43(2), pp.1-25.

Larraín, J., 2001. Identidad Chilena. Santiago de Chile: LOM.

Larraín, F. \& Vergara, R., eds., 2000. La transformación económica de Chile. Santiago de Chile: CEP.

Levitsky, S., 2003. Transforming Labor-Based Parties in Latin America: Argentine Peronism in Comparative Perspective. Cambridge, UK: Cambridge University Press.

Levy, E. \& Valenzuela, D., 2007. La Resurrección. Historia de la post crisis Argentina. Buenos Aires: Editorial Sudamericana. Lewis, P.H., 2009. The Agony of Argentine Capitalism: From Menem to the Kirchners. Santa Barbara: CLIO.

Llach, J., 2003. Está en crisis el paradigma neoliberal. La Nación, 13 Sep.

Lodola, G., 2011. Cultura política de la democracia en Argentina: Consolidación democrática en las Américas en tiempos difíciles. Buenos Aires: Universidad Torcuato Di Tella.

Miller, P. \& Rose N., 2008. Governing the Present: Administering Economic, Social and Personal Life. Cambridge, UK: Polity Press.

Minujin, A. \& Kessler, G., 1997. La nueva pobreza en la Argentina. Buenos Aires: Planeta.

Mayol, A., 2012. El derrumbe del modelo. Santiago de Chile: LOM.

Medved, T., 2012. Think Tanks in America. Chicago: The University of Chicago Press. 
Mirowski, P., 2013. Never let a serious Crisis go to Waste: How Neoliberalism survived the Financial Meltdown. London: Verso.

Mirowski, P. \& Plehwe, D., eds., 2009. The Road from Mont Pelerin. The Making of the Neoliberal Thought Collective. London: HUP.

Mönckeberg, M.O., 2005. La Privatización de las universidades. Una historia de dinero, poder e influencias. Santiago de Chile: Copa Rota. 2007. El negocio de las universidades en Chile. Santiago de Chile: Debate.

2009. Los magnates de la Prensa. Santiago de Chile: Debate.

Montecinos, V., 2009. Economics: the Chilean story. In V. Montecinos \& J. Markoff, eds. Economists in the Americas. Northhampton: Edward Elgar.

Montecinos, V. \& Markoff, J., eds., 2009. Economists in the Americas. Northampton: Edward Elgar.

Montero, C., 1993. El actor empresarial en transición. Colección estudios CIEPLAN, Junio, Santiago.

Moulian, T., 1998. Chile actual: Anatomía de un mito. Santiago de Chile: LOM.

Muñoz Goma, O., 2007. El Modelo Económico de la Concertación 1990-2005: ¿Reformas o Cambio? Santiago de Chile: CIEPLAN/FLACSO.

Novaro, M., 2006. Historia de la Argentina Contemporánea: De Perón a Kirchner. Buenos Aires: Edhasa. 2009. Argentina en el fin de siglo. Democracia, Mercado y Nación. Buenos Aires: Paidos.

Panizza, F., 2009. Contemporary Latin America: Development and Democracy beyond the Washington Consensus. London: Zed Books.

Pavón, H., 2012. Los intelectuales y la política en la Argentina: El combate por las ideas 1983-2012. Buenos Aires: Random House Mondadori.

Peck, J.; Theodore, N. \& Brenner, N., 2009. Postneoliberalism and its Malcontents. Antipode, 41(1), pp.94-116.

Piketty, T., 2014. Capital in the Twenthy-First Century. Cambridge, MA: Harvard University Press.

Piñera, J., 1990. La revolución laboral en Chile. Santiago de Chile: Zigzag.

Polanyi, K., 2001. The Great Transformation: The Political and Economic Origins of our Time. Boston: Beacon Press.

Pucciarelli, A., ed., 2004. Empresarios, tecnócratas y militares. La trama corporativa de la última dictadura. Buenos Aires: Siglo XXI. , ed. 2006. Los años de Alfonsín. ¿El poder de la democracia o la democracia del poder? Buenos Aires: Siglo XXI. , 2011. Los años de Menem. La construcción del orden neoliberal. Buenos Aires: Siglo XXI.

Puryear, J., 1994. Thinking Politics: Intellectuals and Democracy in Chile 1973-1988. Baltimore: John Hopkins University Press.

Riggirozzi, P., 2010. Social Policy in Post-Neo-Liberal Latin America: The Cases of Argentina, Venezuela and Bolivia. Development, 53(1), pp.70-76.

Ruiz, F., 2005. El señor de los mercados: Ámbito financiero, la City y el poder del periodismo económico de Martínez de Hoz a Cavallo. Buenos Aires: El Ateneo.

Schneider, B.R., 2004. Business Politics and the State in Twentieth-Century Latin America. New York: Cambridge University Press.

2009. Hierarchical Market Economies and Varieties of Capitalism in Latin America. Journal of Latin American Studies, 41(4), pp.553-575.

Schumpeter, J., 1976. Capitalism, Socialism and Democracy. New York: Harper Torchbook.

Sehnbruch, K., 2006. The Chilean Labour Market: A key to understanding Latin American Labour Markets. New York: Palgrave.

Silva, E., 1996. The State and Capital in Chile: Business Elites, Technocrats, and Market Economics. Boulder: Westview Press. ,2009. Challenging Neoliberalism in Latin America. New York: Cambridge University Press.

Silva, P., 1991. Technocrats and Politics in Chile: From the Chicago Boys to the CIEPLAN Monks. Journal of Latin American Studies, 23(2), pp.385-410. 2008. In the Name of Reason: Technocrats and Politics in Chile. University Park: Penn State University Press.

Stecher, A., 2013. La modernización de la industria del retail: reorganización empresarial y experiencias laborales. In J. Ossandón \& E. Tironi, eds. Adaptación. La empresa chilena después de Friedman. Santiago de Chile: Ediciones UDP.

Streeck, W., 2010. E Pluribus Unum? Varieties and Commonalities of Capitalism. MPIfG Discussion Paper, 10(12).

Taylor, M., 2006. From Pinochet to the Third Way: Neoliberalism and Social Transformation in Chile. London: Pluto Press.

Taylor, L., 1998. Citizenship, Participation, and Democracy: Changing Dynamics in Chile and Argentina. New York: St. Martin's Press.

Therborn, G., 2011. The World: A Beginner's Guide. London: Polity Press. 2013. The killing Fields of Inequality. London: Polity Press.

Thrift, N., 2005. Knowing Capitalism. London: Sage Publications.

Thumala, M.A., 2007. Riqueza y piedad. El catolicismo de la élite económica chilena. Santiago de Chile: Debate/Random House Mondadori.

Tironi, E., 1999. La irrupción de las masas y el malestar de las elites. Santiago de Chile: Grijalbo. ,2013. Adaptación sin relato. La empresa chilena ante la democracia y la globalización. In: J. Ossandón, J. \& E. Tironi, E., eds. Adaptación. La empresa chilena después de Friedman. Santiago de Chile: Ediciones UDP. 
Tironi, M. \& Zenteno, J., 2013. "Licencia social para operar". Sostenibilidad y las justificaciones de la RSE en la gran minería chilena. In J. Ossandón \& E. Tironi, eds. Adaptación. La empresa chilena después de Friedman. Santiago de Chile: Ediciones UDP.

Undurraga, T., 2012. Transformaciones sociales y fuentes de poder del empresariado chileno (1975-2010). Revista Ensayos de Economía, Universidad Nacional de Colombia, 41(2), pp.201-225.

2013. Instrucción, indulgencia y justificación: los circuitos culturales del capitalismo chileno. In J. Ossandón \& E. Tironi, eds. Adaptación. La empresa chilena después de Friedman. Santiago de Chile: Ediciones Universidad Diego Portales.

2014. Divergencias: trayectorias del neoliberalismo en Argentina y Chile. Santiago de Chile: Ediciones Universidad Diego Portales.

Valdés, J.G., 1995. Pinochet's Economists: The Chicago School in Chile. New York: Cambridge University Press.

Valdivia, V., 2003. El Golpe Después del Golpe. Santiago de Chile: LOM.

Villalón, R., 2007. Neoliberalism, Corruption and Legacies of Contention: Argentina's Social Movements, 1993-2006. Latin American Perspectives, 153(34), pp.139-156.

Wilkinson, R., 2005. The Impact of Inequality: How to make sick Societies healthier. London: Routledge.

Williamson, J., ed. 1990, Latin American Economic Adjustment: How much has happened? Washington, D.C.: Institute for International Economics.

Winn, P., ed., 2004, Victims of the Chilean Miracle: Workers and Neoliberalism in the Pinochet Era, 1973-2002. Durham: Duke University Press.

\section{Newspaper articles}

Mayol, A., 2014. ¿El derrumbe del derrumbe? El Mostrador, 18 August. Available in: http://www.elmostrador.cl/opinion/2014/08/18/el-derrumbe-del-derrumbe/. Accessed 29 May 2015.

Peña, C., 2014. Consensos a la hora del té. El Mercurio, 13 julio. Available in: http://www.elmercurio.com/blogs/2014/07/13/23471/Consensos-a-la-hora-del-te.aspx. Accessed 29 May 2015.

\section{Other sources}

Chile, 1988. Declaración de Principios del Gobierno de Chile. Santiago: Editorial Jurídica de Chile.

Chile. Ministerio de Desarrollo Social, 2011. Encuesta de Caracterización Socio-económica. Santiago: Gobierno de Chile. CEPAL, 2010. Anuario Estadístico de América Latina y el Caribe. Santiago de Chile: Naciones Unidas.

CEPAL, 2011. Panorama de la Inserción Internacional de América Latina y el Caribe 2010-2011. La región en la década de las economías emergentes. Santiago de Chile: Naciones Unidas.

Chile. Dirección del Trabajo, 2011a. Compendio de Series Estadísticas 1990-2010, Capítulo Sindicalismo. 2011b. Compendio Series Estadísticas, Capítulo Negociación.

Fundación Sol, 2013. Minuta de Empleo, 31, Diciembre-Febrero.

ILO, 2008. World of Work Report: Income Inequalities in the Age of Financial Globalization. Geneva: International Labour Office.

IMF. International Monetary Fund, 2011. World Economic Outlook Data Base, Apr. Retrieved from: www.imf.org/external/pubs/ft/weo/2011/01/weodata/index.aspx. Accessed 19 July 2011.

PNUD. Programa de las Naciones Unidas para el Desarrollo, 1998. Desarrollo Humano en Chile: Las paradojas de la modernización. Santiago de Chile.

World Bank, 2002. Globalization, Growth and Poverty. Washington, D.C.: World Bank Publications.

\section{Resumo}

O artigo contrasta as experiências do neoliberalismo na Argentina e no Chile e explora por que dois países que implementaram reformas para o mercado aparentemente semelhantes atingiram posições distintas quanto à mercantilização: uma política pósneoliberal na Argentina e um neoliberalismo temperado no Chile que só recentemente vem sendo questionado. O artigo traça os antecedentes comuns que inspiraram essas reformas e os diferentes resultados e reações que eles produziram. Em contraste com a literatura recente que enfatiza um ou outro fator explicativo,o artigo oferece uma comparação sintética dos fatores históricos, políticos, econômicos e ideológicos em jogo, ajudando a entender como os capitalistas conseguiram uma posição de classe hegemônica no Chile mas não na Argentina.

PALAVRAS-CHAVE: neoliberalismo; Argentina; Chile; pós-neoliberalismo; formação da classe capitalista.

License information: This is an open-access article distributed under the terms of the Creative Commons Attribution License (CC-BY-NC 4.0), which permits unrestricted use, distribution, and reproduction in any medium, provided the original work is properly cited. 